\title{
KAJIAN STRUKTURAL DAN NILAI MORAL DALAM KUMPULAN CERPEN KOMPAS 2015 SERTA PEMANFAATANNYA SEBAGAI BAHAN AJAR BAHASA DAN SASTRA INDONESIA DI SMP
}

\author{
Eli Setiawati \\ Guru SMPN 5 Subang \\ Email: setiawati.191281@gmail.com
}

\begin{abstract}
ABSTRAK
Penelitian ini berjudul Kajian Struktural dan Nilai Moral dalam Kumpulan Cerpen Kompas 2015 serta Pemanfaatanya sebagai Bahan Ajar Bahasa dan Sastra Indonesia di SMP. Tujuan penelitian ini adalah mendeskripsikan struktur intrinsik, mendeskripsikan nilai-nilai moral, mendeskripsikan pemanfaatan hasil kajian kumpulan cerpen Kompas 2015 sebagai bahan ajar apresiasi sastra dari kajian struktur dan nilai-nilai cerpen. Penelitian yang dilakukan ini merupakan penelitian deskriptif kualitatif. Teknik pengumpulan data penelitian dilakukan dengan menggunakan studi kepustakaan dan studi dokumentasi terhadap cerpen Kompas 2015. Langkahlangkah pengumpulan data adalah membaca kumpulan cerpen Kompas 2015 secara cermat, mencatat data yang sesuai, megidentifikasi dan mengklasifikasi data, dan membuat tabulasi data. Hasil penelitian menyebutkan bahwa kumpulan cerpen Kompas 2015 dibangun oleh dua unsur, yaitu fakta dan sarana cerita yang meliputi alur, karakter, latar, sudut pandang, gaya bahasa, dan tema dan unsur pembangun cerita yaitu nilai-nilai yang terkandung dalam cerpen Kompas 2015 khususnya nilai moral.
\end{abstract}

Kata kunci:unsur intrinsik, nilai-nilai moral, cerpen, dan deskriptif.

\begin{abstract}
The research is entitled The Study of Structural and Moral Values in 2015 Compass set of Short Stories and Its use as Bahasa Indonesia Instructional Materials and Literature at Junior High School. The purpose of this study is to describe the intrinsic structure, to describe the moral values, to describe the use of the study results in Compass 2015 collection of short stories as teaching materials of literary appreciation on the study of the structure and values of short stories. This research is a qualitative descriptive study. The data collection techniques of the research uses literature study and documentation of the stories Compass 2015. The steps of data collection is by reading the collection of short stories thoroughfully in Compass 2015, noting the appropriate data, identifying and classifying the data and make the data tabulation. The study presents that the short story collection Compass 2015 was built by two elements, which were the facts and means of stories covering the plot, characters, setting, point of view, style, and theme and also the building blocks of the story which are the values contained in stories Compass 2015, especially moral values.
\end{abstract}

Key words:intrinsic element,, moral values, short stories, and descriptive. 


\section{PENDAHULUAN}

Pengajaran sastra memiliki peran bagi pemupukan kecerdasan siswa dalam semua aspek, termasuk moral. Melalui apresiasi sastra, misalnya kecerdasan intelektual, emosional, dan spiritual siswa dapat dilatih serta dikembangkan. Siswa tidak hanya terlatih untuk membaca saja, tetapi harus mampu mencari makna dan nilai-nilai dalam sebuah karya sastra.

Sastra juga merupakan sarana ekspresi imajinasi manusia. Segala bentuk pemikiran intelektual dan keindahan seni kehidupan manusia dapat diekspresikan melalui sastra. Effendi (Jauhari, 2010:1) mengatakan, bahwa apresiasi sastra adalah kegiatan menggauli karya sastra secara sungguh-sungguh, sehingga menumbuhkan pengertian, kepekaan perasaan, dan ketajaman pemikiran terhadap karya sastra yang diapresiasi.

Kegiatan apresiasi sastra itu harus melibatkan totalitas jiwa, sehingga pemahaman terhadap karya sastra akan matang dan berkembang ke arah yang lebih tinggi. Karya sastra khususnya cerpen sebagai karya seni yang kreatif, artinya sebagai hasil ciptaan manusia yang berupa karya bahasa. Dari zaman ke zaman sudah banyak orang menciptakan karya yang berupa karya yang menggunakan medium bahasa dengan berbagai bentuk dan gaya penulisannya. Karya sastra yang ditulis oleh pengarang tidak semata-mata mengukir keindahan dengan kata-kata, tetapi mereka menyampaikan suatu pesan dan amanat yang ingin disampaikan kepada pembaca.

\section{KAJIAN TEORETIS}

Menurut Hidayati (2015:124), cerita pendek sering disingkat menjadi cerpen, adalah cerita rekaan yang pendek, berbentuk prosa berkesan fiksi. Bahkan ada ahli sastra yang memberinya batasan "cerita yang habis dibaca sekali duduk".
Pendeknya cerita pendek, kita biasanya tidak menemukan adanya perkembangan di dalam cerita itu.

Kosasih (2014:34) mengemukakan, bahwa cerita pendek (cerpen) merupakan cerita yang menurut wujud fisiknya berbentuk pendek. Ukuran panjang pendeknya suatu cerita memang relatif, umumnya cerita yang habis dibaca sekitar sepuluh menit atau setengah jam. Melalui cerpen siswa dapat menemukan ide, pikiran, gagasan dan imajinasinya sehingga siswa akan semakin produktif dalam menghasilkan sebuah karya.

Tim Kementerian Pendidikan dan Kebudayaan (2014:58) mengemukakan, bahwa buku guru dan buku siswa merupakan sarana implementasi kurikulum dalam pembelajaran. Buku guru sebagai pedoman guru dalam melaksanakan pembelajaran sedangkan buku siswa sebagai buku sumber bagi peserta didik. Dilihat dari fenomena pada buku pegangan guru dan buku pegangan siswa, materi struktur cerpen dan nilai moral masih sangat minim. Siswa masih minim pengetahuan tentang struktur dan nilai-nilai yang terkandung dalam karya sastra, terutama cerita pendek. Siswa kesulitan untuk menentukan struktur dan nilai-nilai yang terdapat dalam cerita pendek.

Materi sastra cerpen untuk jenjang SMP, pada kurikulum 2013 mengalami perubahan. Pembelajaran sastra cerpen yang semula pada jenjang kelas VII sekarang mengalami perubahan menjadi kelas IX. Jelaslah materi sastra khususnya cerpen itu sulit diterima oleh siswa di kelas VII, sehingga membutuhkan penelitian yang lebih mendalam terhadap materi cerpen ini.

Kurikulum 2013 merupakan pembelajaran tematik, cerpen yang digunakan dalam proses belajar juga menyesuaikan dengan temanya. Menurut Kemendikbud (2016:3), tema dalam sebuah karya sastra khususnya cerpen harus 
menghindari yang memiliki potensi kekerasan, kekasaran, pornografi, dan memicu konflik SARA.

Nurgiyantoro (2010:322) mengemukakan, bahwa moral dalam karya sastra, atau hikmah yang diperoleh pembaca lewat sastra, selalu dalam pengertian yang baik. Pesan moral sastra lebih memberat pada sifat kodrati manusia yang hakiki, bukan pada aturan-aturan yang dibuat oleh manusia. Banyaknya perilaku yang menyimpang yang dilakukan siswa sehingga pembinaan nilai moral yang diintegrasikan dalam mata pelajaran perlu dilakukan. Pembinaan nilai moral hendaknya memperhatikan juga ranah afektif. Penyampaian ranah afektif harus menggunakan media stimulus, salah satunya adalah cerita pendek. Cerita pendek merupakan media pembelajaran yang mengandung nilainilai moral yang dapat diteladani dan disukai oleh siswa.

Bahan ajar merupakan seperangkat informasi yang harus diserap peserta didik melalui pembelajaran yang menyenangkan (Iskandarwassid, 2008:171). Peserta didik atau siswa harus merasakan manfaat bahan ajar atau materi itu setelah ia mempelajari. Pendapat tersebut mengungkapkan bahwa tujuan utama bahan ajar ialah membantu siswa dalam mencapai standar kompetensi yang telah ditetapkan. Pada materi cerpen di SMP, bahan ajar diperlukan untuk mencapai tujuan tersebut.

Tidak semua cerita pendek bisa dijadikan bahan ajar yang sesuai di sekolah menengah pertama (SMP). Mangunwijaya (dalam Jauhari, 2010:29) mengatakan, bahwa pada awal mula, segala sastra itu religius. Nilai-nilai keagamaan dalam cerpen sangat berhubungan dengan moral yang ada dalam karya sastra itu yang sifatnya menyeru, mengajak, merangsang kepada kebaikan, melarang melakukan kejahatan, dan mengakui kebesaran tuhan. Pada haki- katnya penanaman nilai moral ini berlangsung sejak manusia lahir. Anak sebagai individu yang sedang bertumbuh akan menyerap nilai moral yang didapatnya dari pengalamannya, salah satunya adalah dari kegiatan membaca dan mengapresiasi karya sastra. Isi cerita yang terkandung dalam cerita pendek untuk siswa sekolah menengah pertama (SMP) harus dipilih sesuai kurikulum untuk SMP.

Yanusa Nugroho seorang cerpenis, mengungkapkan pada rubrik pendapat yang terdapat dalam buku kumpulan cerpen Kompas 2015, bahwa standar karya dalam buku "Cerpen Pilihan Kompas" selalu di atas rata-rata karena disaring dari cerpen-cerpen yang dimuat di Kompas minggu. Ini merupakan bentuk kepedulian Kompas dalam memajukan dan mengembangkan kesusastraan Indonesia. Kompas adalah tolak ukur di bidang sastra. Buku kumpulan cerpen pilihan Kompas 2015 yang berjudul "Anak Ini Mau Mengencingi Jakarta?" sebagai buktinya.

Sedangkan menurut Efix Mulyadi yaitu salah satu juri mengatakan cerpen yang berjudul "Anak Ini Mau Mengencingi Jakarta?" karya Ahmad Tohari menjadi metafor yang sangat kuat dan produktif untuk menggambarkan warga masyarakat miskin yang tersisih dan tidak mendapat kesempatan di ibu kota. Penulis-penulis cerpen Kompas merupakan orang-orang yang tidak asing lagi di dunia sastra Indonesia. Oleh karena itu, akan ditemukan banyak penggunaan aspek kebahasaan di dalamnya.

Konsep dan ide baru yang menjadi acuan penulis dalam penelitian ini adalah memberikan contoh rencana pembelajaran bahasa Indonesia dalam apresiasi sastra melalui kajian struktural kumpulan cerita pendek Kompas dan nilai moral yang terkandung di dalamnya. Dengan adanya kajian ini guru dapat berkaca bahwa penganalisisan sebuah karya sas- 
tra dapat membantu siswa mengembangkan ilmu kesastraannya secara mendalam dengan pembelajaran analisis struktur dan nilai moral karya sastra cerpen.

Kajian struktural merupakan salah satu hal penting dalam pembelajaran apresiasi sastra. Menurut Nurgiyantoro (2010:37), kajian struktural dapat dilakukan dengan mengidentifikasi, mengkaji, dan mendeskripsikan fungsi dan hubungan anatarunsur intrinsik cerpen. Dikatakan penting karena dengan adanya kajian struktural dari sebuah karya sastra contohnya cerpen akan memberikan pemahaman yang lebih mendalam bagi siswa mengenal makna isi sebuah cerpen tersebut. Di samping itu, juga memperkaya pengetahuan siswa tentang moral. Cerpen yang merupakan gambaran kehidupan maka siswa dapat mengambil hikmah dan belajar tentang hidup yang sebenarnya.

Penelitian terhadap cerpen perlu sekali dilakukan mengingat pentingnya pemahaman terhadap seluk beluk isi cerpen bagi pembaca yang banyak mengandung manfaat terhadap aspek pembelajaran sastra. Salah satu bentuk penelitian terhadap cerpen adalah kajian struktur pembangun cerpen, unsur nilainilai yang tergantung di dalamnya, dan model pembelajaran sastra cerpen kepada siswa.

Berdasarkan uraian di atas, maka rumusan masalah penelitian ini adalah sebagai berikut: (1) bagaimanakah struktur naratif pada kumpulan cerita pendek Kompas tahun 2015?; (2) bagaimana bentuk nilai moral yang terkandung pada kumpulan cerita pendek Kompas tahun 2015?; dan (3) dapatkah hasil kajian struktural dan nilai moral dalam kumpulan cerita pendek Kompas 2015 dimanfaatkan sebagai bahan ajar bahasa dan sastra Indonesia di SMP?

Berdasarkan rumusan masalah di atas, maka tujuan penelitian ini adalah sebagai berikut: (1) mendeskripsikan struktur naratif pada kumpulan cerita pendek Kompas tahun 2015; (2) mendeskripsikan bentuk nilai moral yang terkandung pada kumpulan cerita pendek Kompas tahun 2015; (3) mendeskripsikan pemanfaatan hasil kajian struktural dan nilai moral dalam kumpulan cerita pendek Kompas 2015 sebagai bahan ajar bahasa dan sastra Indonesia.

Kajian struktural yang dimaksud dalam penelitian ini adalah penelaahan, penyelidikan terhadap kumpulan cerita pendek Kompas tahun 2015 dari unsurunsur pembentuknya, yaitu berupa unsur intrinsiknya dan nilai moral yang terkandung di dalam karya sastra tersebut. Struktur pembentuk cerpen yang terdiri atas unsur-unsur pembangunnya yakni fakta cerita, sarana cerita, dan tema. Fakta cerita terdiri atas alur, tokoh dan penokohan, dan latar. Sarana cerita yang dimaksud adalah sudut pandang pe-garang dan gaya bahasa.

Nilai moral yang dimaksud dalam penelitian ini adalah nilai baik yang terkandung dalam kumpulan cerita pendek Kompas tahun 2015, diharapkan dapat meningkatkan harkat dan martabat manusia sebagai makhluk berbudaya, berpikir, berketuhanan serta membentuk karakter yang baik pada anak sekolah menengah pertama.

Cerita pendek yang dimaksud dalam penelitian ini adalah cerita rekaan yang pendek, yang habis dibaca sekali duduk. Jumlah tokohnya terbatas, jalan ceritanya sederhana dan latarnya meliputi lingkup yang terbatas.

Pemanfaatan bahan ajar yang dimaksud dalam penelitian ini adalah proses, cara memanfaatkan bahan ajar sastra khususnya cerita pendek bagi pendidik dan bagi siswa atau peserta didik. Bahan ajar itu merupakan segala bentuk bahan (baik informasi, alat, maupun teks) yang disusun secara sistematis, yang menampilkan sosok utuh dari kompetensi yang akan dikuasai siswa dan di- 
gunakan untuk membantu guru dalam proses perencanaan, penelaahan implementasi pembelajaran.

\section{METODE PENELITIAN}

Penelitian ini akan menggunakan penelitian kualitatif yang bersifat deskriptif analisis. Deskriptif adalah data terurai dalam bentuk kata-kata atau gambar-gambar, bukan dalam bentuk angka-angka (Semi, 2010:24). Sedangkan menurut Ratna (2015:53), metode deskriptif analisis dilakukan dengan mendeskripsikan fakta-fakta yang kemudian disusul dengan analisis. Mula-mula data dideskripsikan dengan maksud untuk menemukan unsur-unsurnya, kemudian dianalisis, bahkan diperbandingkan. Tujuannya adalah mendeskripsikan data atau memberi gambaran secara sistematis.

Sumber data utama dalam penelitian ini adalah kata-kata, kalimat, pernyataan, ungkapan dalam kumpulan cerpen kompas tahun 2015 dan tindakan selebihnya adalah data tambahan seperti dokumen dan lain-lain. Sumber data utama adalah kumpulan cerpen kompas tahun 2015 yang berjumlah 23 cerpen pilihan kompas dengan pengarang yang berbeda. Dari 23 cerpen pilihan Kompas, dipilih tema cerita yang mendidik dan sesuai dengan kebutuhan siswa SMP kelas IX yaitu sebagai berikut:(1) Anak ini Mau mengencingi Jakarta Karya Ahmad Tohari; (2) Hakim Sarmin karya Agus Noor; (3) Basa-Basi karya Jujur Prananto; (4) Dua Penyanyi karya Budi Darma; (5) Lidah Ketut Rapti karya Ni Komang Ariani; (6) Liang Liu karya Dewi Ria Utari; (7) Batu Lumut Kapas karya Gus Tf Sakai; (8) Sebotol Hujan untuk Sapardi karya Joko Pinurbo; (9) Kebohongan itu Manis, Vardhazh karya Indra Tranggono; (10) Savonette karya Warih Wisatsana; (11) Linuwih Aroma Jarik Baru karya Anggun Prameswari; (12) Tepi Shire karya
Tawakal M Iqbal; (13) Nomor karya Seno Gumira Ajidarma.

Teknik pengumpulan data merupakan cara yang digunakan peneliti untuk mendapatkan data dalam suatu penelitian. Pada penelitian kali ini peneliti menggunakan teknik studi pustaka, studi dokumentasi dan angket.

Teknik analisis data bertujuan untuk mengungkapkan proses perorganisasian dan pengurutan data tentang struktur dan nilai moral yang terdapat dalam cerpen Kompas tahun 2015. Selanjutnya hasilnya dimasukkan ke dalam pola kategori satuan uraian sehingga pada akhirnya dapat ditarik kesimpulan tentang struktur dan nilai moral pada cerpen Kompas. Analisis data yang digunakan dalam penelitian adalah analisis data kualitatif.

\section{HASIL PENELITIAN DAN PEMBAHASAN}

Kajian struktural difokuskan kepada unsur intrinsik yaitu penokohan, alur, latar, gaya bahasa, sudut pandang, dan tema. Sedangkan kajian terhadap nilai moral merujuk pada akhlak terhadap Tuhan Yang Maha Esa, akhlak terhadap sesama manusia, dan akhlak manusia terhadap lingkungan.

Pada cerpen "Anak ini Mau Mengencingi Jakarta?", alur dalam cerita ini menggunakan alur maju atau progresif. Tokoh yang terlibat dalam cerpen ini terdiri dari seorang anak lakilaki berumuran lima tahun, bapak, emak. Latar tempat dalam cerita ini yaitu di pinggiran rel yang menunjukkan latar sosial warga miskin yang tinggal di pinggir rel. Menunjukkan Sudut pandang menggunakan pesona ketiga dengan menyebut nama tokoh dalam cerpen tersebut. Gaya bahasa yang digunakan yaitu majas sinestesia dan hiperbola. Tema yang terkandung dalam keseluruhan cerita yaitu kemiskinan warga di pinggir rel kereta api. Nilai Moral terha- 
dap Tuhan Yang Maha Esa yaitu dengan melaksanakan ibadah sholat lima waktu walaupun ketika berpergian menggunakan kereta api. Aspek terhadap sesama manusia yaitu perilaku kasih sayang ayah kepada anakknya, mengajarkan jangan mempunyai sifat serakah dan tanggung jawab seorang ayah terhadap anak dan istrinya dengan melindunginya. Aspek terhadap lingkungan sosial masyarakat yaitu tidak boleh buang air kecil di tempat umum dan membuang sampah sembarangan.

Pada cerpen Hakim Sarmin, alur dalam cerita ini menggunakan alur mundur atau sorot balik. Tokoh yang terlibat dalam cerpen ini terdiri dari Hakim Sarmin dan seorang perempuan. Latar tempat dalam cerita ini yaitu di pengadilan yang sedang melakukan persidangan serta menunjukkan latar sosial seseorang yang menjabat sebagai hakim dan perempuan sebagai terdakwa kasus pembunuhan. Menunjukkan Sudut pandang menggunakan pesona ketiga dengan menyebutkan nama tokoh yaitu Hakim Sarmin dan perempuan itu. Gaya bahasa yang digunakan yaitu majas simile dan hiperbola. Tema yang terkandung dalam keseluruhan cerita yaitu ketidakadilan hukum. Keadilan sulit didapatkan didunia nyata, hanya kebohongan publik yang ditampilkan oleh pengadilan. Nilai Moral terhadap Tuhan Yang Maha Esa yaitu dengan selalu berbuat kebaikan, menghindari perbuatan yang dilarang oleh agama seperti berbohong, perbuatan perkosaan. Semua yang dilakukan oleh makhluk Tuhan yang melanggar pasti akan mendapatkan balasannya sesuai perbuatannya. Aspek terhadap sesama manusia yaitu perilaku saling menghormati, saling menjaga, saling menghargai, dan saling mengingatkan. Aspek terhadap lingkungan sosial masyarakat yaitu dengan menjaga lingkungan sekitar dengan memelihara ciptaanya.
Pada cerpen Basa Basi, alur dalam cerita ini menggunakan alur mundur atau sorot balik. Tokoh yang terlibat dalam cerpen ini terdiri dari Jumardi, bu Siska, dan Ratih. Latar tempat dalam cerita ini yaitu kantor BUMN, rumah Jumardi, Kantor Menteri Urusan Penanaman Modal Asing yang menunjukkan latar sosial seorang bu Siska yang menjabat sebagai Direktur Utama Perusahaan BUMN dan sekarang menjadi menteri Urusan Penanaman Modal Asing. Latar sosial juga ditunjukkan oleh Jumardi sebagai Direktur Pengawasan di BUMN dan sekarang menjadi tenaga ahli di perusahan asing di Kanada serta Ratih sebagai istrinya. Sudut pandang menggunakan pesona ketiga dengan menyebutkan nama tokonya. Gaya bahasa yang digunakan dalam cerita tersebut menggunakan bahasa yang mudah dimengerti dengan ditunjukkan percakapan antara Jumardi dan bu Siska serta Jumardi dan Ratih. Tema yang terkandung dalam keseluruhan cerita yaitu kebasa-basian ucapan yang sering terjadi di lingkungan kantor. Nilai Moral terhadap Tuhan Yang Maha Esa yaitu dengan mendoakan antarsesama manusia dan meminta tolong kepada Tuhan dengan berdoa. Aspek terhadap sesama manusia yaitu perilaku saling menghormati dan menghargai kepada orang yang lebih tua begitu juga sebaliknya. Aspek terhadap lingkungan sosial masyarakat yaitu untuk menjadi manusia sosial yang selaras, serasi dan seimbang.

Pada cerpen Dua Penyanyi, alur dalam cerita ini menggunakan alur maju, lurus, atau progresif . Tokoh yang terlibat dalam cerpen ini terdiri dari Latiff Ariffin, Latifa, Latif Arifin, Latifah, Sulaiman bin Ariffin dan Sulaiman bin Arifin. Latar tempat dalam cerita ini yaitu rumah Jumardi, rumah sakit, jalan, dan stasiun bawah tanah, serta menunjukkan latar sosial Latiff Ariffin, Latifa, Latif Arifin, Latifah sebagai 
pegawai biasa serta anaknya Sulaiman bin Arifin dan Sulaiman bin Ariffin bekerja sebagai penyanyi di stasiun bawah tanah. Menunjukkan Sudut pandang menggunakan pesona ketiga dengan menyebutkan nama tokoh dalam cerpen tersebut. Gaya bahasa yang digunakan yaitu majas personifikasi dan hiperbola. Tema yang terkandung dalam keseluruhan cerita yaitu takdir kehidupan. Nilai Moral terhadap Tuhan Yang Maha Esa yaitu dengan selalu berdoa, berzikir, dan sembahyang kepada Tuhan secara khusus. Aspek terhadap sesama manusia yaitu perilaku saling tolong menolong ketika orang lain membutuhkan bantuan. Aspek terhadap lingkungan sosial masyarakat yaitu menolong orang yang akan melahirkan.

Pada cerpen Lidah Ketut Rapti, alur dalam cerita ini menggunakan alur maju, lurus, atau progresif. Tokoh yang terlibat dalam cerpen ini terdiri dari Ketut Rapti dan Made. Latar tempat dalam cerita ini yaitu di kantor Ketut Rapti, Karang Asem Bali serta menunjukkan latar sosial Ketut Rapti sebagai pelukis lidah yang terkenal di Jakarta sedangkan Made hanya sebagai pegawai biasa. Menunjukkan Sudut pandang menggunakan pesona ketiga dengan menyebutkan nama tokohnya. Gaya bahasa yang digunakan yaitu majas hiperbola, pras pro toto, ungkapan dan menggunakan bahasa daerah Bali. Tema yang terkandung dalam keseluruhan cerita yaitu keinginan yang besar dari seorang Ketut Rapti agar tekanan $\mathrm{T}$ pada lidah itu akan terlihat lagi. Tekanan itu yang mampu menghasilkan lukisan lidah yang dibanggakan. Nilai Moral terhadap Tuhan Yang Maha Esa yaitu dengan saling tolong menolong dalam kebaikan. Aspek terhadap sesama manusia yaitu perilaku tidak melupakan teman, tidak berprasangka buruk, dan harus saling tolong menolong saat kesulitan. Aspek terhadap lingkungan sosial masyarakat yaitu rasa malu berlebihan yang harus dihindari dalam kehidupan sehari-hari.

Pada cerpen Liang Liu alur dalam cerita ini menggunakan alur campuran yang di dalam ceritanya mengandung alur progresif dan regresif. Tokoh yang terlibat dalam cerpen ini terdiri dari aku dan seorang perempuan. Latar tempat dalam cerita ini yaitu di sebuah tanah yang ditanami pohon liang liu dan rumah perempuan itu serta menunjukkan latar sosial perempuan yang kaya raya. Sudut pandang menggunakan pesona pertama dengan menyebut aku dan pesona ketiga dengan menunjukkan nama perempuan itu. Gaya bahasa yang digunakan yaitu majas personifikasi dan hiperbola. Tema yang terkandung dalam keseluruhan cerita yaitu kejadian masa lalu yang hadir kembali setelah melihat lukisan dari pohon liang liu. Nilai Moral terhadap Tuhan Yang Maha Esa yaitu dengan saling tolong menolong tanpa pamrih dalam kebaikan dan Tuhan akan memberikan balasan yang baik terhadapnya. Aspek terhadap sesama manusia yaitu perilaku saling menghargai, bersikap ramah, dan kita harus meminta izin bila ingin memasuki rumah orang lain. Aspek terhadap lingkungan sosial masyarakat yaitu rasa mencintai terhadap pohon liang liu dengan cara menyiramnya dan memberi pupuk secara berkala.

Pada cerpen Batu Lumut Kapas alur dalam cerita ini menggunakan alur mundur atau sorot balik. Tokoh yang terlibat dalam cerpen ini terdiri dari Tuak Ije, Wan Iju dan Din Kudil. Latar tempat dalam cerita ini yaitu di kampung Suliki serta menunjukkan latar sosial Tuak Ije sebagai kolektor batu akik dan Wan Ijun mencari batu akik untuk diperdagangkan kembali. Sudut pandang yang digunakan dalam cerita ini yaitu menggunakan pesona ketiga dengan menyebutkan nama tokoh dalam cerita tersebut. Gaya bahasa yang digu- 
nakan yaitu personifikasi dan hiperbola. Tema yang terkandung dalam keseluruhan cerita yaitu batu akik. Nilai Moral terhadap Tuhan Yang Maha Esa yaitu dengan tidak berbohong untu kepuasan diri sendiri. Aspek terhadap sesama manusia yaitu perilaku membantu temannya yang sedang membutuhkan. Aspek terhadap lingkungan sosial masyarakat yaitu membantu orang yang mengalami kematian.

Pada cerpen Sebotol Hujan Untuk Sapardi, alur dalam cerita ini menggunakan alur maju atau lurus. Tokoh yang terlibat dalam cerpen ini terdiri dari saya, Subagus dan Sapardi. Latar tempat dalam cerita ini yaitu di rumah Sapardi serta latar sosial menunjukkan saya sebagai pegawai yang mapan dan mencintai puisi-puisi Sapardi Djoko Damono dan Sapardi sebagai penyair terkenal. Menunjukkan Sudut pandang menggunakan pesona pertama dengan menyebut saya dan pesona ketiga dengan menyebut nama Subagus dan Sapardi. Gaya bahasa yang digunakan yaitu majas personifikasi. Tema yang terkandung dalam keseluruhan cerita yaitu keinginan atau impian menemui tokoh idolanya yaitu Sapardi Djoko Damono. Nilai Moral terhadap Tuhan Yang Maha Esa yaitu dengan menghargai setiap rezeki yang diberi oleh Tuhan. Aspek terhadap sesama manusia yaitu perilaku membantu temannya yang sedang kesulitan ingin bertemu Sapardi, menghargai pemberian orang lain, mengucapkan terima kasih atas pemberian hadiah, menghormati orang yang lebih tua. Aspek terhadap lingkungan sosial masyarakat yaitu menghargai nilai hujan adalah anugerah Tuhan dengan cara mensyukurinya.

Pada cerpen Kebohongan itu Manis, Vardhazh, alur dalam cerita ini menggunakan alur maju atau lurus. Tokoh yang terlibat dalam cerpen ini terdiri dari Presiden Grig Gaz,
Vardhazh, dan nyonya Zabarthini. Latar tempat dalam cerita ini yaitu Negara Repbulik Garpallo, tempat pemakaman, vila di Bukit Sutra serta menunjukkan latar sosial Tuan Grag sebagai presiden yang berpura-pura meninggal, Vardhazh sebagai presiden pengganti Tuan Grag dan nyonya Zabarthini adalah istri keempat Tuan Grag. Menunjukkan Sudut pandang menggunakan pesona ketiga dengan menyebut nama tokoh. Gaya bahasa yang digunakan yaitu majas personifikasi dan hiperbola. Tema yang terkandung dalam keseluruhan cerita yaitu kebohongan publik seorang presiden kepada rakyatnya dengan berpurapura meninggal. Nilai Moral terhadap Tuhan Yang Maha Esa yaitu sebagai umat Tuhan kita harus menghindari prilaku berbohong. Aspek terhadap sesama manusia yaitu perilaku tidak mengolokolok kepada orang lain. Aspek terhadap lingkungan sosial masyarakat yaitu kita harus menghormati dan menghargai tempat pemakaman sebagai tempat untuk mendoakaan orang yang sudah meninggal, bukan dipakai sebagai tempat pesta untum merayakan kematian seseorang.

Pada cerpen Savonette, alur dalam cerita ini menggunakan alur mundur atau sorot balik. Tokoh yang terlibat dalam cerpen ini terdiri dari aku dan lelaki tua. Latar tempat dalam cerita ini yaitu di rumah, kantor, stasiun kereta api dan tempat reparasi arloji serta menunjukkan latar sosial saya sebagai pegawai yang mapan dan lelaki tua yang mempunyai pekerjaan sebagai tukang reparasi arloji. Menunjukkan Sudut pandang menggunakan pesona pertama dengan menyebut aku dan pesona ketiga dengan menyebut lelaki tua itu. Gaya bahasa yang digunakan yaitu majas hiperbola. Tema yang terkandung dalam keseluruhan cerita yaitu jam yang membawa keberuntungan. Nilai Moral terhadap Tuhan Yang Maha Esa yaitu meminta 
tolong kepada Tuhan dengan cara melaksanakan perubahan hidup yang jujur, ikhlas dalam bekerja, serta berdoa dengan keras. Aspek terhadap hubungan dengan sesama manusia yaitu tidak berprasangkan buruk terhadap seseorang. Aspek terhadap lingkungan sosial masyarakat yaitu merawat barang-barang antik atau sudah tua dengan penuh cinta.

Pada cerpen Linuwih Aroma Jarik Baru, alur dalam cerita ini menggunakan alur mundur atau sorot balik. Tokoh yang terlibat dalam cerpen ini terdiri dari seorang perempuan dan ibu dari perempuan itu. Latar tempat dalam cerita ini yaitu di rumah, pasar, pelaminan bapaknya serta menunjukkan latar sosial perempuan itu seorang yang mempunyai kelebihan. Menunjukkan Sudut pandang menggunakan pesona ketiga dengan menyebut perempuan itu dan menyebut tokoh ibu. Gaya bahasa yang digunakan yaitu majas personifikasi, hiperbola, dan menggunakan bahasa Jawa. Tema yang terkandung dalam keseluruhan cerita yaitu tanda-tanda kematian. Nilai Moral terhadap Tuhan Yang Maha Esa yaitu kebesaran Tuhan dengan menghidupkan kembali orang yang sudah meninggal dengan diberikanya suatu kelebihan dengan mengetahui siapa yang akan meninggal. Aspek terhadap hubungan dengan sesama manusia yaitu saling menyayangi antara ibu dan anaknya dan menghormati ibunya dengan berbakti, taat kepadanya. Aspek terhadap lingkungan sosial masyarakat yaitu mencintai ciri khas Jawa adalah kain batik.

Pada cerpen Tepi Shire, alur dalam cerita ini menggunakan alur maju atau progresif. Tokoh yang terlibat dalam cerpen ini terdiri dari aku dan lelaki tua tukang sapu. Latar tempat dalam cerita ini yaitu di Sungai Shire serta latar sosial aku sebagai pegawai yang mapan dan lelaki tua yang mempunyai pekerjaan sebagai tukang sapu di tempat sungai
Shire. Menunjukkan Sudut pandang menggunakan pesona pertama dengan menyebut aku dan pesona ketiga dengan menyebut lelaki tua itu. Gaya bahasa yang digunakan yaitu majas hiperbola dan asosiasi. Tema yang terkandung dalam keseluruhan cerita yaitu perasaan putus asa. Nilai Moral terhadap Tuhan Yang Maha Esa yaitu meminta tolong kepada Tuhan dengan cara berdoa, tawakal dan sabar. Aspek terhadap hubungan dengan sesama manusia yaitu saling menghormati dan menghargai keberadaan orang yang ada disekitar kita. Aspek terhadap lingkungan sosial masyarakat yaitu mencintai sungai Shire sebagai tempat untuk menyelesaikan pekerjaannya setiap musim gugur.

Pada cerpen Nomor, alur dalam cerita ini menggunakan alur mundur atau sorot balik. Tokoh yang terlibat dalam cerpen ini terdiri dari aku, perempuan itu dan lelaki itu. Latar tempat dalam cerita ini yaitu tidak ditunjukkan secara jelas serta menunjukkan latar sosial aku sebagai seseorang yang sudah meninggal secara misterius dan mayat tubuhnya entah di mana. Menunjukkan Sudut pandang menggunakan pesona pertama dengan menyebut aku dan pesona ketiga dengan menyebut perempuan itu dan lelaki itu. Gaya bahasa yang digunakan yaitu majas hiperbola. Tema yang terkandung dalam keseluruhan cerita yaitu kematian yang terjadi di masa lalu dan misterius. Nilai Moral terhadap Tuhan Yang Maha Esa yaitu Tuhan menciptakan takdir, untuk itu kita sebagai makhluknya harus menjalani dan meyakininya. Aspek terhadap hubungan dengan sesama manusia yaitu mengingat orang yang sudah meninggal. Aspek terhadap lingkungan sosial masyarakat yaitu merawat barang pemberian yang diwariskan oleh ibu dan kakek karena di dalamnya terdapat warisan cerita.

Sebagai bahan pengajaran sastra khususnya dalam mengkaji cerpen de- 
ngan tepat, beberapa aspek yang perlu diperhatikan. Menurut Rahmanto (2005, 27-31), ada tiga aspek penting yang tidak boleh dilupakan jika ingin memilih bahan pembelajaran sastra, yaitu: (1) bahasa; (2) kematangan jiwa (psikologi), (3) latar belakang kebudayaan siswa.

1. Aspek bahasa

Pertimbangan aspek bahasa yaitu dalam setiap cerpennya pasti mengandung gaya bahasa untuk memperindah paparan cerpen. Gaya bahasa yang terdapat dalam kumpulan cerpen Kompas 2015 dominan majas personifikasi dan majas hiperbola. Majas asosiasi, simile, pras pro toto juga tampak dalam cerpen di atas. Diselingi oleh bahasa daerah yang terdapat dalam cerpen Lidah ketut Rapti yaitu bahasa Bali dan dalam cerpen Linuwih Aroma Jarik Baru yang menggunakan bahasa daerah Jawa. Bahasa personifikasi dan hiperbola yang banyak terkandung dalam cerpen ini, menyulitkan siswa untuk mengerti isi dalam cerpen ini. Majas tersebut sudah sering dipelajari tetapi mereka kadang sulit untuk menjangkaunya dalam cerpen Kompas 2015 ini, karena katakatanya yang terlalu tinggi untuk anak SMP.

2. Kematangan jiwa (psikologi)

Pertimbangan aspek psikologi dalam kumpulan cerpen Kompas 2015 banyak menyuguhkan realitas sosial dari segi perwatakan yang sering ditemui siswa SMP dikehidupannya. Masalah-masalah perwatakan itu sangat dekat dengan kehidupan siswa. Seperti sikap bertanggungjawab dan penyayang dalam cerpen "Anak ini Mau Mengencingi Jakarta?", mengajarkan moral bertanggungjawab dan sikap saling menyayangi dilingkungan keluarga. Perilaku pemberani harus ditiru untuk memberi semangat dalam kehidupan yang dijalani siswa. Sikap pembohong, minder, penakut harus dihindari agar memupuk moral yang lebih baik. Pada akhirnya, siswa akan menemukan sebuah keputusan moral yang dapat diteladani tentang baik dan buruknya suatu tingkah laku atau peristiwa dalam cerpen dan menghubungkan dengan kehidupan sehari-hari.

3. Latar belakang kebudayaan siswa

Pertimbangan latar belakang budaya dari kumpulan cerpen Kompas 2015 banyak menampilkan tema-tema tentang kehidupan sosial dari tokoh Pada umumnya, latar tempat yang digunakan dalam kumpulan cerpen Kompas 2015 adalah lingkungan sosial kelas bawah, menengah dan atas. Seperti ditunjukkan pada tempat pinggir rel, kantor BUMN, tempat pelukis terkenal, sebuah kampung. Penggunaan tema, tokoh, dan latar seperti tersebut di atas akan mampu menarik minat siswa untuk mempelajari sastra. Hal ini disebabkan oleh adanya perasaan kedekatan siswa dengan cerita yang dibaca. Mereka akan mudah memahami cerita karena telah mengenal budaya yang terdapat dalam cerpen.

\section{SIMPULAN}

Dalam cerpen 1 sampai cerpen 13 memiliki alur regresif maupun progresif, dan karakter dalam cerpen memiliki karakter yang berbeda-beda, latar meliputi latar tempat, waktu, dan suasana, sudut pandang memakai pesona pertama dan ketiga, gaya bahasa yang digunakan dalam cerpen 1 sampai 13 memakai gaya bahasa yang paling dominan yaitu personifikasi dan hiperbola, tema yang diangkat dalam cerpen 1 sampai 13 bertema bermacam-macam. Dalam hal nilai-nilai moral cerpen 1 sampai 13 memiliki nilai yang berkenaan dengan akhlak kepada Tuhan, sesama manusia, dan lingkungan.

Dalam penelitian ini kumpulan cerpen Kompas 2015 digunakan untuk dijadikan modul atau seperangkat pembelajaran apresiasi sastra. Ketigabelas cerpen yang telah dikaji dapat digunakan sebagai alternatif bahan ajar 
pembelajaran Bahasa Indonesia dalam apresiasi sastra kelas IX SMP. Hasil kajian ini dapat digunakan sebagai pelengkap dari materi pelajaran apresiasi sastra.

\section{DAFTAR PUSTAKA}

Hidayati, P.P. (2015). Pembelajaran Menulis Esai Berorientasi Peta Berpikir Kritis. Bandung: Prisma Press.

Hidayati, P.P. (2015). Pedoman Penulisan Tesis. Bandung: Universitas Pasundan.

Iskandarwassid dan Dadang Suhendar. (2008). Strategi Pembelajaran Bahasa. Bandung: PT Remaja Rosdakarya.

Kosasih, E. (2014). Dasar-Dasar Keterampilan Bersastra. Bandung: Yrama Widya.

Nurgiyantoro.Burhan. (2010) .Teori Pengkajian Fiksi. Yogyakarta: Gajah Mada University Press.

Nurgiyantoro,Burhan.(2010). Penilaian Pembelajaran Bahasa. Yogyakarta: BPFE- Yogyakarta.

Ratna, K.N. (2015). Teori Metode, dan Teknik Penelitian Sastra. Yogyakarta: Pustaka Pelajar.

Semi, Atar. (2010). Metode Penelitian Sastra. Bandung: Angkasa.

Tim Kemendikbud. (2014). Materi Pelatihan Guru Implementasi Kurikulum 2013 SMP/ Mts Bahasa Indonesia. Jakarta: Badan Pengembangan Sumber Daya Manusia Pendidikan dan Kebudayaan dan Penjaminan Mutu Pendidikan.

Tim Kementerian Pendidikan dan Kebudayaan. (2016). Kompetensi Inti dan Kompetensi Dasar Sekolah Menengah Pertamal Madrasah Tsanawiah (SMP/ MTs). Jakarta: Kementerian Pendidikan dan Kebudayaan. 